\title{
Embodied energy and operational energy computations for a typical G+3 residential building in Vijayawada city of Andhra Pradesh, India
}

\author{
Jagadish Vengala ${ }^{1}$, K. Ramesh ${ }^{2}$, Manjunatha $M^{3^{*}}$, Manish S Dhare ${ }^{4}$ and B Krishna Siva Kumar ${ }^{5}$ \\ Associate Profes sor, Department of Civil Engineering, PVP Siddhartha Institute of Technology, Vijayawada, India ${ }^{1}$ \\ Professor and Head, Department of Civil Engineering, PVP Siddhartha Institute of Technology, Vijayawada, India ${ }^{2}$ \\ Assistant Professor, Department of Civil Engineering, GITAM University, Bangalore, Karnataka, India ${ }^{3}$ \\ Research Scholar, Department of Civil Engineering, BMS College of Engineering, Bangalore, India ${ }^{4}$ \\ UG Student, Department of Civil Engineering, PVP Siddhartha Institute of Technology, Vijayawada, India ${ }^{5}$
}

Received: 02-June-2021; Revised: 16-August-2021; Accepted: 18-August-2021

(C2021 Jagadish Vengala et al. This is an open access article distributed under the Creative Commons Attribution (CC BY) License, which permits unrestricted use, distribution, and reproduction in any medium, provided the original work is properly cited.

\begin{abstract}
Energy computations in commercial and residential buildings have been studied over the past few years by various researchers. The studies have revealed an interesting relation between the materials used in the building, the manufacturing process, the construction process, and its overall impact on the environment. However, limited studies have been conducted on the computation of the Embodied Energy (EE) and the Operational Energy $(O E)$ of residential buildings. In the present investigation, an attempt has been made to compute these two factors (EE and $O E$ ) for a residential building situated in Vijayawada, Andhra Pradesh, India. The case study chosen here is an exciting example of a reinforced cement concrete framed structure with ground + three floors. Based on the conducted studies, the EE computations show that a huge amount of energy is used for materials such as cement, steel, and bricks. The use of alternative building materials to these and technologies can help in reducing $\mathrm{EE}$. OE can be reduced during the lifetime of the building by implementing different methods of energy conservation. The energy consumption in a typical residential building depends on the types of appliances, usage hours, the consumption of the devices, etc. Changes in any one of these could alter the annual energy consumption, and thus, the $O E$. The EE content is experienced once separately from maintenance and renovation, whereas $O E$ gathers over time and can be prejudiced throughout the life of the structure.
\end{abstract}

Keywords

Residential buildings, OE, Energy computations, EE, Thermal comfort.

\section{Introduction}

As the building industry takes up a significant part in the energy utilization of a country, builders and engineers are searching for better approaches to limit the energy utilization in buildings in order to prevent environmental pollution $[1,2]$. The Operational Energy (OE) of buildings alone corresponds to 30 $40 \%$ of the complete power consumption globally [3]. The building sector may be looked at while the motorist that is prominent of use and greenhouse gasoline emissions if embodied requirements. Hence, Embodied Energy (EE) and OE linked to building materials and transport requirements linked to the transportation to build people tend to be taken into consideration [4].

\footnotetext{
*Author for correspondence
}

Among these reasons, decreasing the power usage and greenhouse gas emissions throughout the lifespan of the buildings is the focus of numerous studies.

However, predicated on the significant reviews related to the topic, most of the current research studies have been found to only quantify the operational and embodied power, omitting the transport demands [5]. The evaluations are tied to these two factors of the building when it comes to the working energy, and the embodied energy computation is ignored. Limiting the energy demand and controlling environmental pollution has a huge effect on climate change [6]. In addition, the contribution of the construction sector is significant to these factors [7], and optimumstrategies are required to control these factors. The energy consumed by buildings or other structures is significant because of their massiveness and life compared to other energy consumers such as 
machinery, automobiles, etc. [8, 9]. Computation of the life cycle energy and embodied energy is significant because every building component is built using high-energy materials such as steel, cement, burnt bricks, concrete and its products, etc. [10, 11]. The use of these materials has increased considerably, and a huge amount of energy is consumed during their manufacturing and transportation [12]. There is a need to quantify the energy involved in construction, i.e., the $\mathrm{EE}$ and the $\mathrm{OE}$, so that their depreciation can be implemented in further works as well as in the usage of materials [13, 14]. Increased use of construction materials leads to carbon emissions, which contribute to global warming [15-18]. Construction materials such as cement, aluminum, glass, concrete, etc., contribute to approximately $10 \%$ of the total $\mathrm{CO}_{2}$ in the environment [19-22]. The objectives of the present study are as follows:

- Computation of EE of the building components

- Analysis of OE during the usage of building .

- Measures for reducing the energy consumption and the overall $\mathrm{EE}$ and $\mathrm{OE}$ for the building.

The building industry is a predominant consumer of energy and a large carbon emitter. Thus, EE and $\mathrm{OE}$ are the two vital parameters that have a significant role in managing the adverse impact of the building industry on the environment [23]. Very few scientific studies have focused on assessing the energy consumed during the lifespan of a building and the cost repercussions of numerous energy reduction methods over the different machines associated with the built environment, especially in the Asian subcontinent. With the increasing population in the continent, the demand for dwellings has also increased; thus, directly impacting the demand for building materials. To successfully reduce the energy consumed in the built environment, it is critical to ensure that the solutions are efficient from the financial point of view and technically feasible [24]. The research that quantifies the lifespan, which balances the benefits and value requirements of various energy reduction steps, emphasizes the embodied, useful, and specific transport power when providing the solution for the life of the building [25, 26]. This could identify the essential affordable steps that give the maximum energy cost savings and can offer insights that could lead to unprecedented levels of decreased overall energy usage in domestic buildings. This paper focuses on $\mathrm{EE}$ and $\mathrm{OE}$ studies for a typical mid-rise residential building that is very common in urban scenarios and occupies a significant chunk of houses in urban areas in India. The scope of the investigation is restricted to the computation of EE of a residential building comprising of a Reinforced Cement Concrete (RCC) framed structure located in Vijayawada city, Andhra Pradesh, India. The following components have been considered in these computations:

- Isolated foundation inclusive of Plain Cement Concrete (PCC) bed

- Plinth beam

- Columns, beams, slabs

- Concrete and steel, bricks and mortar and

- Plastering, painting, flooring, and other items.

\section{Literature review}

The natural capital of the land is wincing owing to the use of sustainable and uncontrolled human resources resulting from population growth. At a rate that exceeds the ability of the Earth to replenish, resources such as raw materials, fuels, biomass, and water are being continuously drawn. Pollution, greenhouse gas emissions, waste generation, and land degradation are the major effects of this increased resource use, as is also supported by studies [27, 28]. The consumption of energy in the activities building like transport, construction, and construction is a significant contributor to the global emissions of $\mathrm{CO}_{2}$. By the end of 2050, the worldwide population is anticipated to reach 10 billion people. It is vital to note that a large amount of this growth is occurring in countries where the amount of international $\mathrm{CO}_{2}$ emissions is the highest. A few research reports [29, 30] have quantified the total energy use of different structures during their lifespan across different scales about the built environment or the combined life period power and expense analyses.

Norman et al. [31] have compared the life pattern power usage of large structures around Toronto, Canada, including transport demands. However, their research, particularly underestimates embodied demands.

Fuller and Crawford [32] have analyzed the life cycle of power, i.e., the total and greenhouse gas emissions of various housing patterns close to Melbourne, Australia. This is undoubtedly an extensive study for quantifying EE. However, their research does not perhaps examine the power consumed in certain practices and their financial feasibility because they depend on hybrid (EE and $\mathrm{OE}$ ).

Stephan and Crawford [33] and Stephan et al. [34] have studied the life of the total power profile of various residential structures in the Australian Continent, Belgium, and Lebanon, including 
embodied, operational, and transport requirements. However, they have not considered the financial requirements in their scientific studies.

A considerable amount of energy (40\%) and nonenergy sources such as construction equipment, water (16\%), fuels, electricity, and labour are consumed by the construction industry $[35,36]$, which contributes to $\mathrm{CO} 2$ emissions and waste generation. Approximately $40 \%$ of the global supply of raw stone, gravel, and sand, and $25 \%$ of natural timber are reduced each year owing to building activities [37, 38]. Buildings utilize energy during the construction, operation, maintenance, remodelling, and demolition phases of their life cycle. Energy is also consumed in producing construction materials. Widely used building materials, such as cement, steel, aluminum, and insulation, are potent [39].

All the products and procedures used forconstructing a building comprise the early EE [40]. This factor is also maintained and restored when the building is occupied, and some parts are periodically replaced. These processes, known as repetitive EE, directly and indirectly consume energy [41]. When a building is demolished during the final stage of its life, the materials used in it comprise direct and indirect energy that is either to be recycled, has been recycled, or disposed of. This component of energy is called the dissipation force $[42,43]$. The entire life cycle is the sum of the EE of the initial, repetitive, and demolished energy of a building $[44,45]$. The energy consumption during the entire life cycle of a building involves $\mathrm{EE}$ and $\mathrm{OE}$. The $\mathrm{OE}$ is consumed in lighting, air conditioning, and power building equipment. EE and OE computation play a significant role in choosing the right materials required for reducing energy consumption and making the construction sector ecoand environmental-friendly. Similarly, utilization of industrial by-products as alternative building materials reduces the challenges of disposal of waste byproducts and reduces the energy consumption required for manufacturing the same. Likewise, this study attempts, in the Indian context, to reduce the OE and $\mathrm{EE}$ in the building sector for selecting the right materials for construction by considering a typical ground + three floors residential buildings in Vijayawada City of Andhra Pradesh.

\section{Methodology}

This section describes the methodology adopted for computing the $\mathrm{EE}$ and $\mathrm{OE}$ for a typical mid-rise urban residential building in the Indian scenario. Figure 1 depicts the method adopted in the present study.

\subsection{Case study of a residential building located in Vijayawada}

The residential building considered for the study is located at Vijayawada City, Andhra Pradesh, India. Figure 2 exhibits the typical floor plan of a residential building. The building is an RCC framed structure and comprises three floors, including a stilt and open terrace. Each floor consists of three bedrooms, a hall, a kitchen, and a balcony. Front view of the house is shown in Figure 3, which presents the precise dimensions of the building, including the thickness of the walls. The drawing was prepared after doing manual measurements for each floor, where various structural components of the building were identified and computed. The selection of the building materials is important for reducing the transportation cost and the overall cost of the material. Building materials such as bricks, steel, cement, and other materials were procured from the local market. The EE of each building material involved in the structure was identified from the literature [46, 47], computed, and aggregated to calculate the total EE.

\subsection{Computation of $\mathrm{EE}$ of the residential building} The EE values of various materials were computed for the residential building considered for the study. The values of $\mathrm{EE}$ were taken from the literature [47], considering the Indian scenario. Table 1 lists the $\mathrm{EE}$ values of different building materials considered from the available studies $[46,47]$. The values computed are the upper bounds wherever multiple reports are available. Manual measurements were done for each floor, and various structural components of the building were computed manually. Primary building materials were tabulated. Table 2 lists the EE values of the quantified materials for the residential building.

\subsection{Computation of $\mathrm{OE}$ of the residential building} Unlike EE, the consumption of OE depends on the occupants of a building. The energy required during the lifespan of a building from its commissioning to its end of life, not including renovation and maintenance, is defined as $\mathrm{OE}$. The computation of $\mathrm{OE}$ is relatively simple compared to that of EE. The energy used to $\mathrm{cool} /$ heat the premises, hot water, lights, etc., is computed while the building is in use. Out of the total primary energy consumption, $37 \%$ of the total consumption in India is by the residential sector. Table 3 gives the OEvalues of the components used in the residential building considered in this study. Among the components, Air Conditioners (ACs) contribute the most to energy consumption, i.e., $49 \%$, almost half the total OE. The significant components apart from 
Jagadish Vengala et al.

ACs are refrigerators, lights, geysers, and fans in decreasing order. The total annual OE is $128.67 \mathrm{GJ}$, and the OE for a building in use (50 y) is 6433.5 GJ.

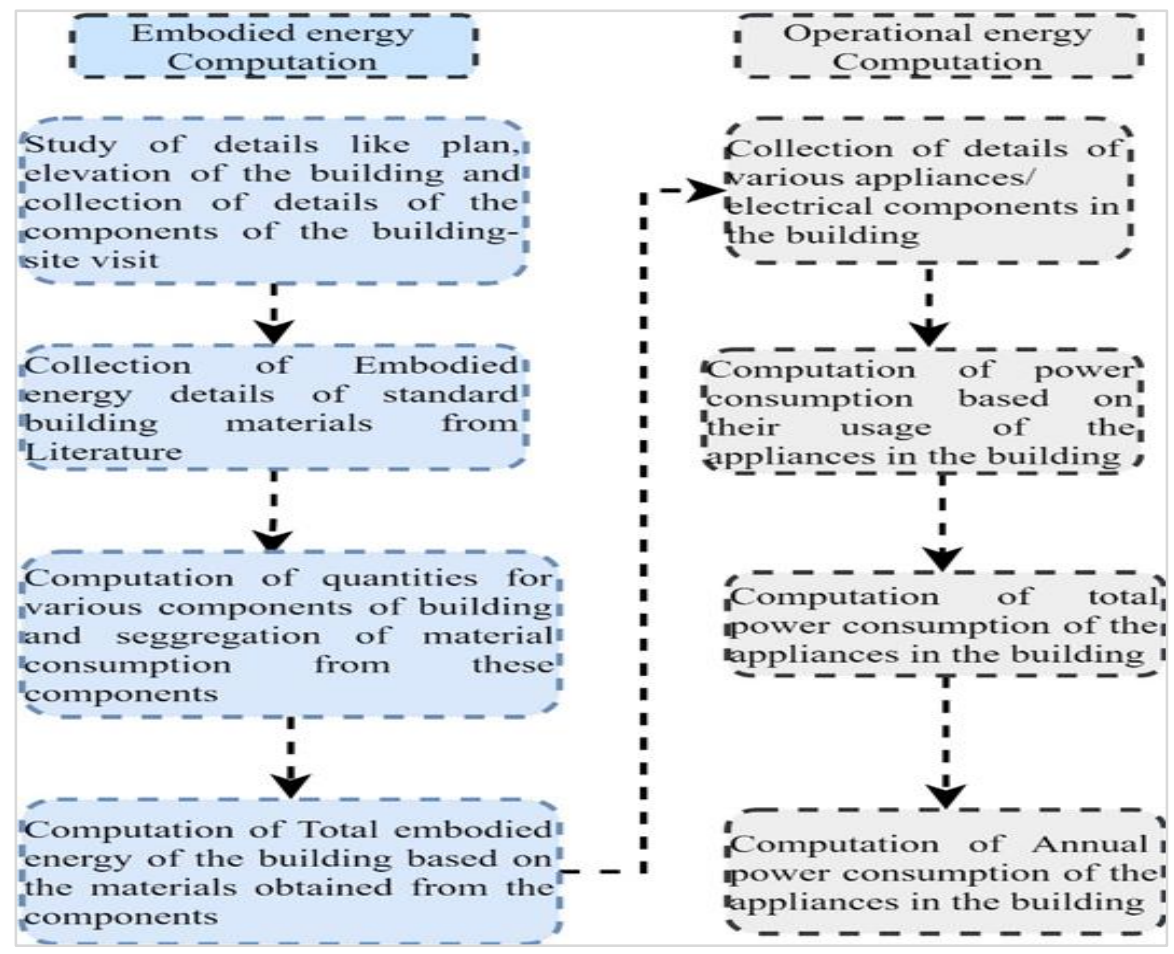

Figure 1 Methodology adopted for the present study

Table 1 Embodied energy values considered from the studies [46, 47]

\begin{tabular}{lll}
\hline Material & Unit & Embodied energy (MJ/ Unit) \\
\hline Cement & $\mathrm{kg}$ & 6.4 \\
\hline Sand & $\mathrm{kg}$ & 0.11 \\
\hline Coarse aggregate & $\mathrm{kg}$ & 0.11 \\
\hline Steel & $\mathrm{Kg}$ & 30.0 \\
\hline Bricks & No & 4.4 \\
\hline Paint & sq.m & 39.24 \\
\hline Floor Tiles & sq.m & 157.4 \\
\hline
\end{tabular}

Table 2 Embodied energy values of the materials quantified for the residential building

\begin{tabular}{|c|c|c|c|c|c|}
\hline Material & $\begin{array}{l}\text { Quantity } \\
\text { (Units) }\end{array}$ & $\begin{array}{l}\text { Embodied } \\
\text { energy } \\
\text { (GJ)/Unit }\end{array}$ & $\begin{array}{l}\text { Embodied } \\
\text { energy of } \\
\text { materials (GJ) }\end{array}$ & $\begin{array}{l}\text { \% of } \\
\text { Embodied } \\
\text { energy }\end{array}$ & Remarks \\
\hline Cement & $146253(\mathrm{~kg})$ & $0.0056 / \mathrm{kg}$ & 936.0 & 36.18 & $\begin{array}{l}\text { Concreting for } \mathrm{RCC} \text { components, } \\
\text { PCC work, plastering, brick } \\
\text { masonry work }\end{array}$ \\
\hline Sand & $624716(\mathrm{~kg})$ & $0.11 /$ ton & 68.7 & 2.66 & $\begin{array}{l}\text { Concreting for } \mathrm{RCC} \text { components, } \\
\text { PCC work, plastering, brick } \\
\text { masonry work }\end{array}$ \\
\hline $\begin{array}{l}\text { Coarse } \\
\text { aggregate }\end{array}$ & $520151(\mathrm{~kg})$ & $0.11 /$ ton & 57.2 & 2.21 & $\begin{array}{l}\text { Concreting for RCC components, } \\
\text { PCC work, }\end{array}$ \\
\hline Steel & $28500(\mathrm{~kg})$ & $30 /$ ton & 855.0 & 33.05 & $\begin{array}{l}\text { RCC component in Foundation, } \\
\text { Columns, Beams, Slab }\end{array}$ \\
\hline Bricks & 100435 (Nos) & $0.00425 / \mathrm{no}$ & 442.0 & 17.09 & $\begin{array}{l}\text { Brick work in sub and super } \\
\text { structure }\end{array}$ \\
\hline
\end{tabular}


International Journal of Advanced Technology and Engineering Exploration, Vol 8(81)

\begin{tabular}{|c|c|c|c|c|}
\hline Material & $\begin{array}{l}\text { Quantity } \\
\text { (Units) }\end{array}$ & $\begin{array}{l}\text { Embodied } \\
\text { energy } \\
\text { (GJ)/Unit }\end{array}$ & $\begin{array}{l}\text { Embodied } \\
\text { energy of } \\
\text { materials (GJ) }\end{array}$ & $\begin{array}{l}\text { \% of Remarks } \\
\text { Embodied } \\
\text { energy }\end{array}$ \\
\hline Paint & 2257 (sq.m.) & $0.03924 / \mathrm{sq} . \mathrm{m}$ & 88.6 & 3.42 \\
\hline Floor Tiles & 885 (sq.m.) & $0.1574 / \mathrm{sq} . \mathrm{m}$. & 139.3 & 5.38 \\
\hline \multicolumn{3}{|c|}{ Total Embodied Energy } & \multicolumn{2}{|l|}{$2586 \mathrm{GJ}$} \\
\hline \multicolumn{3}{|c|}{ Total Embodied Energy in $\mathrm{GJ} / \mathrm{m}^{2}$} & \multicolumn{2}{|l|}{3.1} \\
\hline
\end{tabular}

Table 3 Operational energy values of the components used for the residential building

\begin{tabular}{|c|c|c|c|c|c|c|}
\hline Component & Number & $\begin{array}{l}\text { Energy } \\
\text { consumption (W) }\end{array}$ & $\begin{array}{l}\text { Usage } \\
\text { (hour/day) }\end{array}$ & $\begin{array}{l}\text { Total power } \\
\text { consumption }(W)\end{array}$ & $\begin{array}{l}\text { Annual energy } \\
\text { consumption (MJ) }\end{array}$ & $\begin{array}{l}\text { Operational } \\
\text { energy }(\%)\end{array}$ \\
\hline Fan & 14 & 60 & 6 & 840 & 6623 & 5.1 \\
\hline Light & 50 & 30 & 7 & 1500 & 13797 & 10.7 \\
\hline Geyser & 3 & 1000 & 2 & 3000 & 7884 & 6.1 \\
\hline A C & 3 & 2000 & 8 & 8000 & 63072 & 49.0 \\
\hline Refrigerator & 3 & 240 & 24 & 720 & 22706 & 17.6 \\
\hline Television & 3 & 80 & 7 & 240 & 2208 & 1.7 \\
\hline $\begin{array}{l}\text { Washing } \\
\text { Machine }\end{array}$ & 3 & 280 & 1 & 840 & 1104 & 0.9 \\
\hline Exhaust fan & 40 & 4 & 120 & 631 & 3 & 0.5 \\
\hline Mixer grinder & 400 & 0.5 & 1200 & 788 & 3 & 0.6 \\
\hline Lift & 1 & 3750 & 2 & 3750 & 9855 & 7.7 \\
\hline \multicolumn{5}{|c|}{ Total Annual Energy in GJ } & 128.67 & \\
\hline \multicolumn{5}{|c|}{ Operational Energy (50 Years) in GJ } & 6433.5 & $835 \mathrm{~m}^{2}$ \\
\hline \multicolumn{5}{|c|}{ Operational Energy in $\mathrm{GJ} / \mathrm{m}^{2}$} & 7.70 & \\
\hline \multicolumn{5}{|c|}{ Operational Energy for $\mathrm{AC}$ in $\mathrm{GJ} / \mathrm{m}^{2}$} & 3.78 & \\
\hline
\end{tabular}

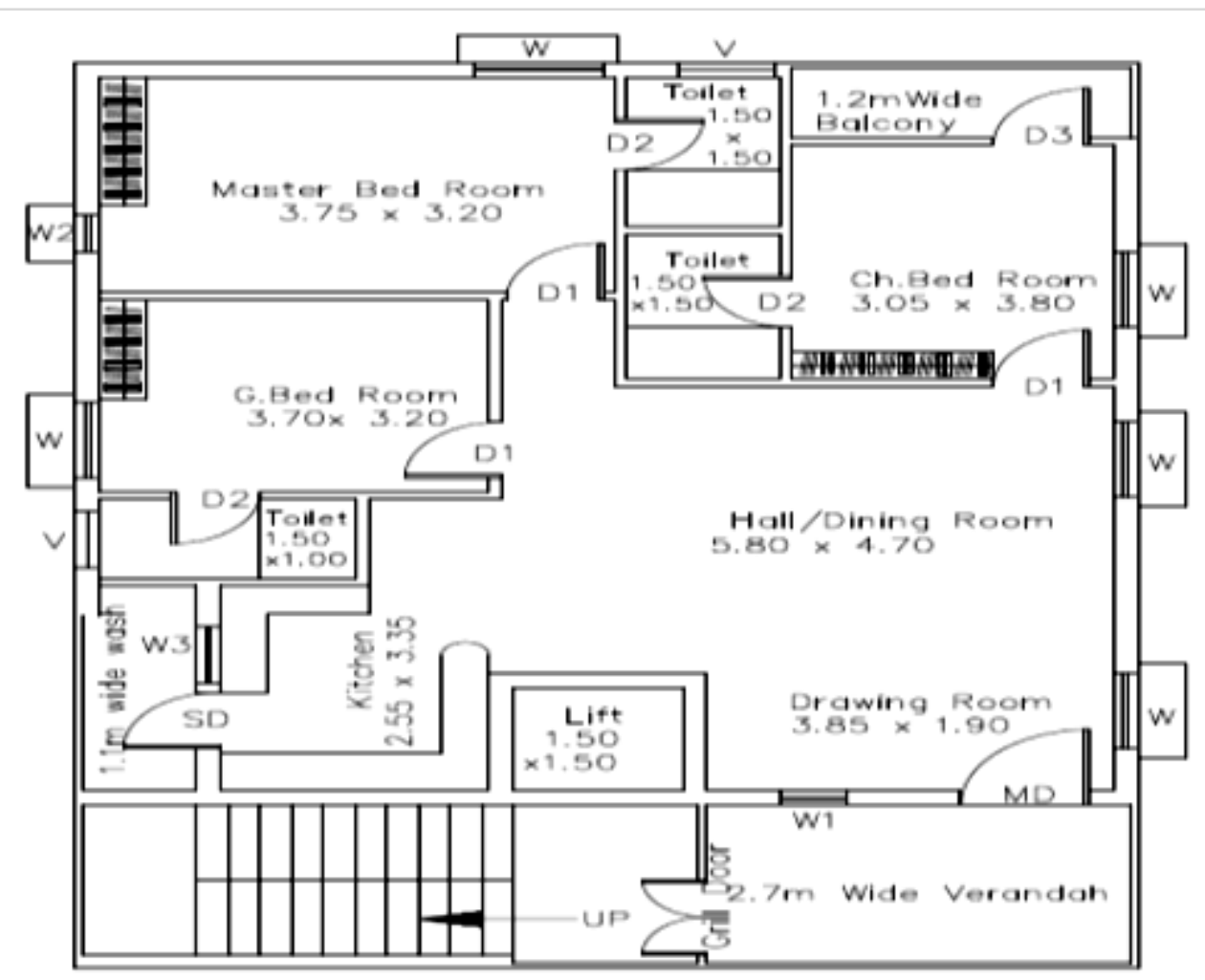

Figure 2 Typical floor plan of the Residential building considered for the study 


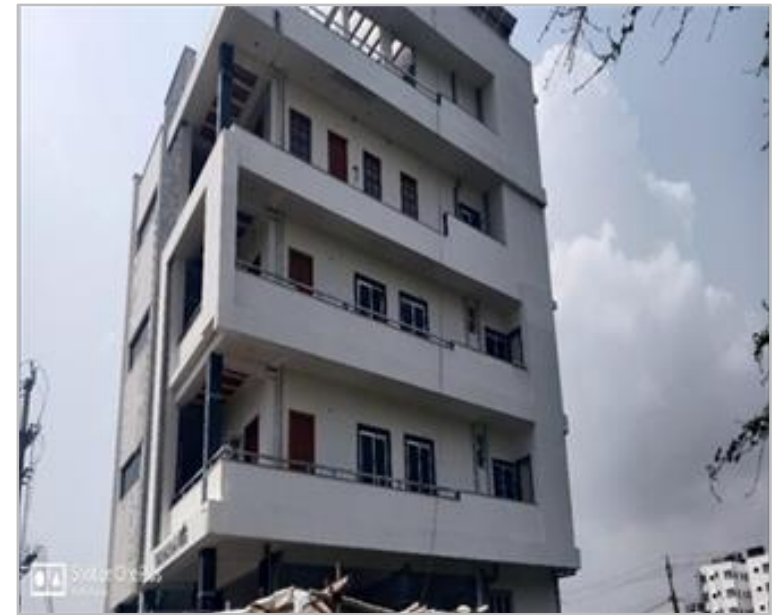

Figure 3 View of the Residential building considered for the study in the city of Vijayawada, Andhra Pradesh

\section{Results and discussion}

\subsection{Embodied energy}

From Table 1, it can be seen that the cement used for the building contributes $36 \%$ to the total $\mathrm{EE}$, followed by steel $(33 \%)$ and bricks $(17 \%)$. The total $\mathrm{EE}$ is computed to be $3.1 \mathrm{GJ} / \mathrm{m} 2$. Apart from the above three components, building materials such as floor tiles and aggregate contribute approximately equally, and their total contribution is approximately $10 \%$. The percentage contribution of painting is about $3.4 \%$. Timber and glass contribute to less than $0.1 \%$ and hence have been neglected in this study. The percentage contribution of each of these materials is shown in Figures 4. The EE computations show that a significant amount of energy is used for materials such as cement, steel, and bricks. In their place, the use of alternative building materials and technologies can help to reduce the value of EE. For example, if a flyash or Ground-Granulated Blast-Furnace Slag (GGBS) is used as a partial replacement (up to 30\%) for cement, the value $\mathrm{EE}$ reduces from $36 \%$ to $30 \%$, which is a reduction of $17 \%$ in the $\mathrm{EE}$ of cementitious material. For masonry work, if a hollow concrete block is used in place of burnt clay brick, the $\mathrm{EE}$ values, reduce from $17 \%$ to $6 \%$, a reduction of $64 \%$ in the $\mathrm{EE}$ value.

\subsection{Operational energy}

As the total $\mathrm{OE}$ is approximately $3.76 \mathrm{GJ} / \mathrm{m} 2$, without $\mathrm{AC}$, only $\mathrm{OE}$ of $\mathrm{AC}$ load is $3.78 \mathrm{GJ} / \mathrm{m} 2$. Figure 5 exhibits the percentage annual $\mathrm{OE}$ values for the various components of the building. The AC load contribution to the $\mathrm{OE}$ value of a typical residential building in a city located in a hot and dry region such as Vijayawada is almost equivalent to the total load 1054 value. This clearly shows that the thermal comfort of the building is considerably affected, and significant load results from cooling the rooms from the inside. Measures need to be taken to reduce the heat transfer in the building through the building envelope. Various methods are available to control the heat flow through the building fabrics, such as walls and roofs. By incorporating hollow blocks and Solar Reflective Index (SRI) paints, the thermal comfort inside the building can be improved. Similarly, for the roof portion, the methods such as cool roof coating and glazed reflecting tiles will improve human comfort inside the building. The EE content is incurred once apart from maintenance and renovation, whereas $\mathrm{OE}$ accumulates with time and can be affected throughout the lifespan of the building.

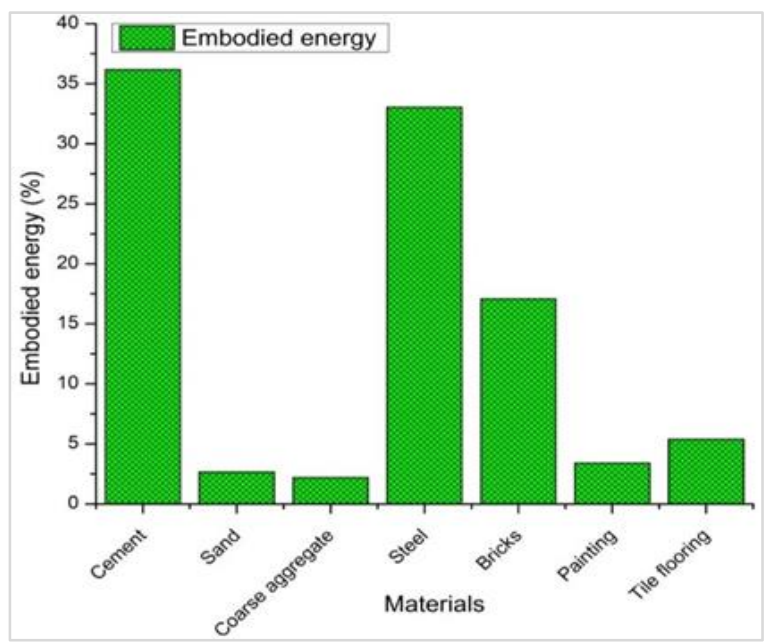

Figure 4 Embodied energy (\%) of various building materials used in the building

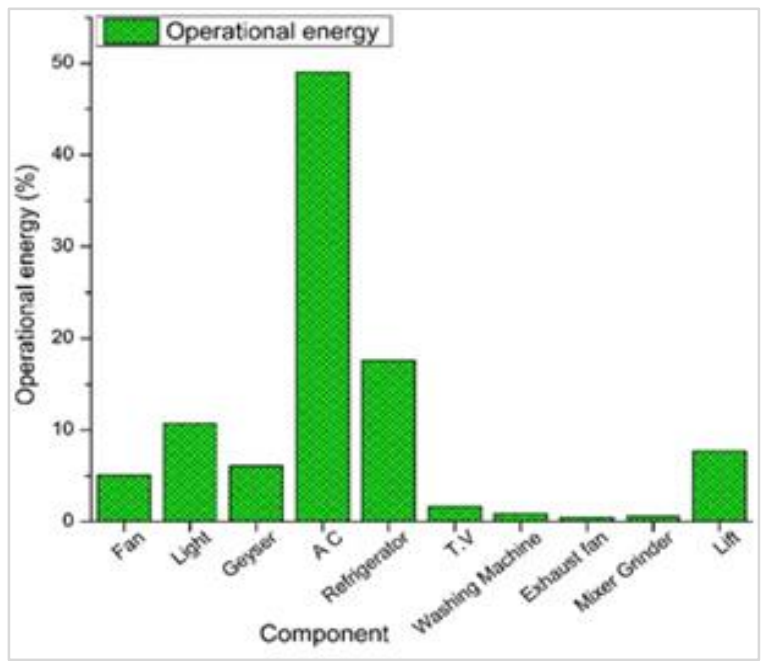

Figure $5 \%$ of Annual operational energy values for various components of the building 


\section{Conclusions}

After a detailed computational analysis, it can be concluded from this study that limiting the energy demand and controlling environmental pollution has a significant effect on climate change. The contribution from the construction sector to these factors is substantial and optimum strategies are required to control them. In this study, an attempt has been made to compute the $\mathrm{EE}$ and $\mathrm{OE}$ values of a residential building situated in Vijayawada, Andhra Pradesh. In particular, the EE values of the various building materials have been estimated in this work. The case study chosen here is an exciting example of an RCC structure with ground + three floors. The cement used for the building was observed to contribute $36 \%$ to the total EE, followed by steel (33\%) and bricks (17\%). The total computed $\mathrm{EE}$ was calculated to be 3.1 $\mathrm{GJ} / \mathrm{m} 2$. Alternative measures for reducing the $\mathrm{EE}$ in buildings, including the usage of recycled materials, transportation, using solar energy, replacing cement with fly-ash and GGBS, building interior products, should also be considered. As the total $\mathrm{OE}$ is calculated to be approximately $3.76 \mathrm{GJ} / \mathrm{m} 2$, without $\mathrm{AC}$, the only OE of AC load is calculated to be 3.78 $\mathrm{GJ} / \mathrm{m} 2$. The $\mathrm{AC}$ load contribution to the $\mathrm{OE}$ for a typical residential building in a city located in a hot and dry region such as Vijayawada is almost equivalent to the totalload. This clearly shows that the thermal comfort of the building is significantly affected, and considerable load results from cooling the rooms in the building from the inside. Measures must be taken to decrease the heat transfer in a building through the building envelope. The EE content is incurred once apart from the upkeep and renovation, whereas $\mathrm{OE}$ accumulates over time and can be affected throughout the lifespan of the building. This study quantified the lifespan that is the energy and cost and steps to minimize by concentrating on embodied, useful, and transportation of energy requirements. This tends to be meant by this comprehensiveness being many with lowering energy use and effects and that can be linked ecological you appear in the built environment are usually grabbed simultaneously. It permits testing of various energy reduction actions together with the identification of the most economical and useful steps. This study offers a foundation for future power reduction strategies for residential structures by giving recommendations for reducing energy consumption to every single contributor associated with the built environment centred on the quantified benefits. This can ultimately reduce the adverse impact of energy consumption on the environment and create a healthier built environment.

1055

\subsection{Scope for future work}

- This study included computation of EE and OE for a typical mid-rise urban building in India comprising of ground plus three stories and using a conventional RCC framed structural system. This work can be extended by comparing the $\mathrm{EE}$ values for a load-bearing structural system consisting of stabilized mud blocks/hollow concrete block systems.

- Since the roofing system in a typical building consumes a considerable amount of material, such as steel and concrete, studies can be carried out by considering alternative roofing materials, such as filler slabs, jack arch roofing, and study their impact in reducing $\mathrm{EE}$.

- Studies can be conducted to find the relationship between $\mathrm{EE}, \mathrm{OE}$, capital cost, and maintenance cost. The impact of cool roof coatings in reducing the OE of the building can be done in future studies.

\section{Acknowledgment}

None.

Conflicts of interest

The authors have no conflicts of interest to declare.

\section{References}

[1] Alwan Z, Nawarathna A, Ayman R, Zhu M, Elghazi Y. Framework for parametric assessment of operational and embodied energy impacts utilising BIM. Journal of Building Engineering. 2021; 42:1-15.

[2] Su X, Tian S, Shao X, Zhao X. Embodied and operational energy and carbon emissions of passive building in HSCW zone in China: a case study. Energy and Buildings. 2020.

[3] Pakdel A, Ayatollahi H, Sattary S. Embodied energy and $\mathrm{CO} 2$ emissions of life cycle assessment (LCA) in the traditional and contemporary Iranian construction sy stems. Journal of Building Engineering. 2021.

[4] Dascalaki EG, Argiropoulou P, Balaras CA, Droutsa KG, Kontoyiannidis S. Analysis of the embodied energy of construction materials in the life cycle assessment of Hellenic residential buildings. Energy and Buildings. 2021.

[5] García-sanz-calcedo J, D SNN, Fernandes JP. Measurement of embodied carbon and energy of HVAC facilities in healthcare centers. Journal of Cleaner Production. 2021.

[6] Shadram F, Mukkavaara J. Exploring the effects of several energy efficiency measures on the embodied/operational energy trade-off: a case study of Swedish residential buildings. Energy and Buildings. 2019; 183:283-96.

[7] Kumar N, Brijbhushan S, Maneeth PD, Shreenivas RS, Siddharth B. Experimental study on strength properties of concrete replacing cement by marble dust and sand by iron ore tailings. International Journal of Advanced 
Technology and Engineering Exploration. 2018; 5(45):255-61.

[8] Venkatraj V, Dixit MK. Life cycle embodied energy analysis of higher education buildings: a comparison between different LCI methodologies. Renewable and Sustainable Energy Reviews. 2021.

[9] Vengala J. Comparison of embodied energy in different bamboo-based houses. In advances in sustainable construction materials 2020 (pp. 197-208). Springer, Singapore.

[10] Ajayi SO, Oyedele LO, Ilori OM. Changing significance of embodied energy: a comparative study of material specifications and building energy sources. Journal of Building Engineering. 2019; 23:324-33.

[11] Cabeza LF, Boquera L, Chàfer M, Vérez D. Embodied energy and embodied carbon of structural building materials: worldwide progress and barriers through literature map analysis. Energy and Buildings. 2021.

[12] Manjunatha M, Preethi S, Mounika HG, Niveditha KN. Life cycle assessment (LCA) of concrete prepared with sustainable cement-based materials. Materials Today: Proceedings. 2021.

[13] Li CZ, Lai X, Xiao B, Tam VW, Guo S, Zhao Y. A holistic review on life cycle energy of buildings: an analy sis from 2009 to 2019. Renewable and Sustainable Energy Reviews. 2020.

[14] Vengala J, Nath SK, Pandey CN. Energy consumption of wood based panel products: a review. Journal of the Indian Academy of Wood Science. 2011; 8:80-3.

[15] Tangadagi RB, Manjunatha M, Bharath A, Preethi S. Utilization of steel slag as an eco-friendly material in concrete for construction. Journal of Green Engineering. 2020; 10(5):2408-19.

[16] Preethi S, Tangadagi RB, Manjunatha M, Bharath A. Sustainable effect of chemically treated aggregates on bond strength of bitumen. Journal of Green Engineering. 2020; 10:5076-89.

[17] Manjunatha M, Raju KV, Sivapullaiah PV. Effect of PVC dust on the performance of cement concrete - a sustainable approach. In recent developments in sustainable infrastructure 2021 (pp. 607-17). Springer, Singapore.

[18] Ashwini K, Rao PS. Behavior of concrete using alccofine and nano-silica under elevated temperature. International Journal of Advanced Technology and Engineering Exploration. 2021; 8(78):600-18.

[19] Reshma TV, Manjunatha M, Bharath A, Tangadagi RB, Vengala J, Manjunatha LR. Influence of $\mathrm{ZnO}$ and $\mathrm{TiO}_{2}$ on mechanical and durability properties of concrete prepared with and without polypropylene fibers. Materialia. 2021

[20] Tangadagi RB, Manjunatha M, Preethi S, Bharath A, Reshma TV. Strength characteristics of concrete using coconut shell as a coarse aggregate-a sustainable ap proach. Materials Today: Proceedings. 2021.

[21] Tangadagi RB, Manjunatha M, Seth D, Preethi S. Role of mineral admixtures on strength and durability of high strength self compacting concrete: an experimental study. Materialia. 2021.
[22] Agustina AF, Saloma S, Nurjannah SA, Usman AP, Hanafiah H. Numerical analy sis of the behavior of light concrete panels with variations of thickness and door opening position in resisting static monotonic loads (similarity). International Journal of Advanced Technology and Engineering Exploration. 2020; 7(73):201-19.

[23] Septriansyah V, Saggaff A. Characteristics of nanocomposite poly mer with temperature variation and heating time by using simple mixing method. International Journal of Advanced Technology and Engineering Exploration. 2021; 8(78):651-61.

[24] Abbasi S. Noorzai E. The BIM-based multioptimization approach in order to determine the tradeoff between embodied and operation energy focused on renewable energy use. Journal of Cleaner Production. 2021.

[25] Minunno R. O'gradv T. Morrison GM. Gruner RL. Investigating the embodied energy and carbon of buildings: a systematic literature review and metaanalysis of life cycle assessments. Renewable and Sustainable Energy Reviews. 2021.

[26] Shirazi A. Ashuri B. Embodied life cvcle assessment (LCA) comparison of residential building retrofit measures in Atlanta. Building and Environment. 2020.

[27] Adegbey e MJ, Reddy PR, Obaisi AI, Elghandour MM, Oyebamiji KJ, Salem AZ, et al. Sustainable agriculture options for production. greenhouse gasses and pollution alleviation, and nutrient recycling in emerging and transitional nations-an overview. Journal of Cleaner Production. 2020.

[28] Nguyen TK, Ngo HH, Guo W, Nguyen TL, Chang SW, Nouven DD, et al. Environmental impacts and greenhouse gas emissions assessment for energy recovery and material recycle of the wastewater treatment plant. Science of The Total Environment. 2021.

[29] Su X. Zhang X. A detailed analvsis of the embodied energy and carbon emissions of steel-construction residential buildings in China. Energy and Buildings. 2016; 119:323-30.

[30] Kumanayake R, Luo H, Paulusz N. Assessment of material related embodied carbon of an office building in Sri Lanka. Energy and Buildings. 2018; 166:250-7.

[31] Norman J, Maclean HL, Kennedy CA. Comparinghigh and low residential density: life-cycle analysis of energy use and greenhouse gas emissions. Journal of Urban Planning and Development. 2006: 132(1):10-21.

[32] Fuller RJ, Crawford RH. Impact of past and future residential housing development patterns on energy demand and related emissions. Journal of Housing and the Built Environment. 2011; 26:165-83.

[33] Stephan A. Crawford RH. A multi-scale life-cvcle energy and greenhouse-gas emissions analysis model for residential buildings. Architectural Science Review. 2014; 57(1):39-48.

[34] Stephan A, Crawford RH, De MK. A comprehensive assessment of the life cvcle energy demand of passive houses. Applied Energy. 2013; 112:23-34. 
[35] Juanico LE. Thermal insulation of roofs by using multiple air gaps separated by insulating layers of low infrared emissivity. Construction and Building Materials. 2020.

[36] Stephan A, Stephan L. Life cycle energy and cost analysis of embodied, operational and user-transport energy reduction measures for residential buildings. Applied Energv. 2016: 161:445-64.

[37] Torres-rivas A, Pozo C, Palumbo M, Ewertowska A, Jiménez L, Boer D. Systematic combination of insulation biomaterials to enhance energy and environmental efficiency in buildings. Construction and Building Materials. 2021.

[38] Ekinci A. Effect of preparation methods on strength and microstructural properties of cemented marine clay. Construction and Building Materials. 2019.

[39] Koh CH, Kraniotis D. A review of material properties and performance of straw bale as building material. Construction and Building Materials. 2020.

[40] Selvaranjan K, Navaratnam S, Gamage JC, Thamboo J, Siddique R, Zhang J, et al. Thermal and environmental impact analysis of rice husk ash-based mortar as insulating wall plaster. Construction and Building Materials. 2021.

[41] Meek AH, Elchalakani M, Beckett CT, Grant T. Alternative stabilised rammed earth materials incorporating recycled waste and industrial byproducts: life cvcle assessment. Construction and Building Materials. 2021.

[42] Lam KL, Kenway SJ, Lane JL, Islam KN, De BRB. Energy intensity and embodied energy flow in Australia: an input-output analysis. Journal of Cleaner Production. 2019: 226:357-68.

[43] Guo S, Zheng S, Hu Y, Hong J, Wu X, Tang M. Embodied energy use in the global construction industry. Applied Energy. 2019.

[44] Muguda S, Lucas G, Hughes PN, Augarde CE, Perlot C. Bruno AW. et al. Durabilitv and hverosconic behaviour of biopolymer stabilised earthen construction materials. Construction and Building Materials. 2020.

[45] Dixit MK. Life cycle recurrent embodied energy calculation of buildings: a review. Journal of Cleaner Production. 2019; 209:731-54.

[46] Sabnis A, Pranesh MR. Sustainability evaluation of buildings in pre-use phase using figure of merit as a new tool. Energy and Buildings. 2017; 145:121-9.

[47] https://edgebuildings.com/wn content/uploads/2017/12/IFC-India-ConstructionMaterials-Database-Methodology-Report.pdf. Accessed 26 April 2021.

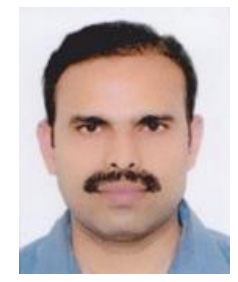

Dr. Jagadish Vengala is currently working as Associate professor, Department of Civil Engineering, PVP Siddhartha Institute of Technology, Vijayawada. He was a former Head, Department of Civil Engineering, BMSIT, Bangalore and Former Scientist at IPIRTI (under MoEF, Govt of India), Bangalore. He has got more than 20 years of Industry, Research and Teaching experience. He was the recipient of ICI - Prof. V. Ramakrishnan Young Scientist award for the year 2008-2009 by Indian Concrete Institute. He has published more than 35 Publications in various Journals and conferences.

Email: jdvengala@gmail.com

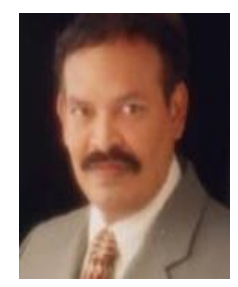

Dr. K. Ramesh is currently working as Professor \& Head, Department of Civil Engineering, PVP Siddhartha Institute of Technology, Vijayawada. He has got more than 30 years of Teaching experience. He was recipient of Dr. Abdul Kalam Life time Achievement national Award from International Institute for Social and Economic reforms ${ }^{\circledR}$, Bangalore in the year 2019. He has published more than 40 Publications in various Journals and conferences.

Email: kookutlaramesh@yahoo.co.in

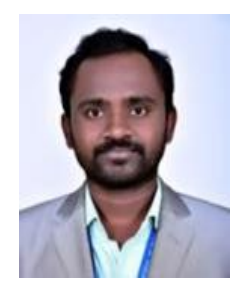

Mr. Manjunatha $\mathbf{M}$ received his $\mathbf{M}$. Tech in Construction Technology from Visvesvaray a Technological University, Karnataka. Currently pursuing Ph.D in Construction Materials and is working as Assistant Professor in Department of Civil Engineering, GITAM University, Bengaluru, India. He has published 23 papers in International Journals and Conferences till date. Email: mmaddike@ gitam.edu

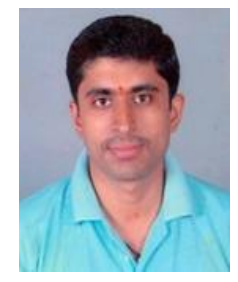

Mr. Manish S Dharek is currently working as a Research Scholar at BMS College of Engineering, Bangalore. He was a former Assistant professor, BMS Institute of Technology \& M anagement, Bengaluru. He has got more than 12 years of Industry, Research and Teaching experience. He received Gold Medal \& 1st Rank for Master's Program in Construction Technology under VTU, Belagavi during 2011. He has guided more than $12 \mathrm{UG}$ and 4 PG Projects.

Email: manish.shashikant@gmail.com 
Jagadish Vengala et al.

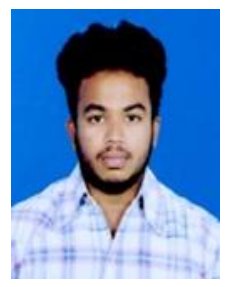

Mr. B Krishna Siva Kumar completed his Bachelor of Engineering in Civil Engineering from PVP Siddhartha Institute of Technology, Vijay awada in 2020.

Email: krishnakanna30@gmail.com

\section{Appendix I}

\begin{tabular}{lll}
\hline S. No. & Abbre viation & Description \\
\hline 1 & AC & Air Conditioner \\
\hline 2 & $\mathrm{CO}_{2}$ & Carbon Dioxide \\
\hline 3 & EE & Embodied Energy \\
\hline 4 & GJ & Giga Joules \\
\hline 6 & GJ/m & Giga joules per square meter \\
\hline 7 & $\mathrm{~kg}$ & Kilogram \\
\hline 8 & $\mathrm{~m}$ & Meter \\
\hline 9 & MJ & Million joules \\
\hline 10 & m ${ }^{2}$ & Meter square \\
\hline 11 & No. & Number \\
\hline 12 & Nos & Numbers \\
\hline 13 & PCC & Operational Energy \\
\hline 14 & RCC & Plain Cement Concrete \\
\hline 15 & SRI & Reinforced Cement Concrete \\
\hline 16 & sq.m & Solar reflective index \\
\hline 17 & ton & Square meter \\
\hline & & Tonne
\end{tabular}

